\title{
Research in inflammatory bowel disease in Brazil: a step forward towards patient care
}

Kotze PG, Damião AOMC. Research in inflammatory bowel disease in Brazil: a step forward towards patient care. Arq Gastroenterol. 2020;57(3):225-6.

Over recent years, significant advances in different areas of inflammatory bowel diseases (IBD), namely Crohn's disease (CD) and ulcerative colitis (UC), were observed throughout the globe. New data that influenced clinical practice included the approval of biologics with different mechanisms of action and small molecules $^{(1-3)}$, updated strategies such as the treat-to-target approach ${ }^{(4)}$, the timely use of biological agents ${ }^{(5)}$ and possible advantages of early surgery ${ }^{(6)}$. Critical studies at a global level changed how we treat $\mathrm{CD}$ and $\mathrm{UC}$ in the last decade, resulting in improved patient care quality and better clinical outcomes.

Brazil is one of the largest countries in the world. Over the last decades, the incidence and prevalence of IBD seem to be increasing in our country, in a profile that seems different than other Latin American countries ${ }^{(7,8)}$. As compared to countries such as Colombia, Mexico, and Argentina, the UC:CD ratio in Brazil is proximal to one in different areas of the federation, a similar disease distribution as countries from North America and Europe ${ }^{(9)}$. This means that we have more cases of CD than other countries in the same continent, a characteristic that is observed in more developed areas of the world. Urbanization, the characteristics of a western diet, added to a different genetic profile (mostly due to European influence in the southern and southeastern regions), are factors that could justify this difference ${ }^{(10-12)}$.

In parallel with the national growing incidence and prevalence of both CD and UC, the interest in IBD management across the country also increased. Several IBD referral centers were developed more recently, aiming at multidisciplinary care of these challenging diseases. As a natural consequence, different areas of research in IBD were developed, and the number of publications in basic science, epidemiology, clinical and surgical aspects covering IBD significantly increased ${ }^{(8,12-16)}$. Brazilian research centers regularly participate in pivotal global clinical trials, which mirrors the development of IBD care and research level in our country.

In this issue of Arquivos de Gastroenterologia, typical examples of recent research in the IBD field are published and call the attention of the global scientific community. Queiroz et al., in a systematic review of the literature with meta-analysis, discussed the relevant issue of discontinuation rates as a consequence of a switch from an originator product to a biosimilar ${ }^{(17)}$. Including 30 studies, their results pointed out that discontinuation rates were $8 \%$ in 6 months, $14 \%$ in 12 months, and $21 \%$ at 24 months. Soon, Brazilian physicians will have several options of biosimilars of the same drug, and knowledge of the consequences of switching must be clarified. Despite the limited quality and heterogeneity of most included studies, this is one of the first literature reviews on this subject and deserves our readers' attention.

Parra et al. demonstrated the prevalence of anemia and iron deficiency in a large cohort of IBD patients $(n=579)$ from a tertiary referral center from midwestern São Paulo state ${ }^{(18)}$. Anemia is one of the most neglected clinical situations in IBD patients and surely needs to be better assessed in our patients. It was important to note that only $35.5 \%$ of the patients were fully screened for anemia, emphasizing the need for clinical practice improvement. The prevalence of anemia was $29.1 \%$ in CD and $19.1 \%$ in UC $(P=0.008)$. Iron deficiency was identified in $53.6 \%$ of $\mathrm{CD}$ and $51.2 \%$ of $\mathrm{UC}$ patients $(P=0.95)$. Anemia was more prevalent in $\mathrm{CD}(\mathrm{OR}=1.76$, 95\% CI 1.16-2.66; $P=0.008)$ as compared to UC, and in active IBD $(\mathrm{OR}=2.61,95 \%$ CI $1.56-4.36 ; P=0.0003)$ as compared to clinical remission. No differences in anemia prevalence were observed in the analysis of $\mathrm{CD}$ location, age of diagnosis, $\mathrm{UC}$ extension, and biological therapy. These data emphasize the need for proactive investigation and treatment of anemia in IBD, a common clinical scenario often associated with fatigue and reduced quality of life.

Differential diagnoses of active IBD are also crucial in patients with $\mathrm{CD}$ or UC, as $C$. difficile infections may mimic active UC. Bertges and Chebli describe in detail the findings of an exciting study evaluating the prevalence and associated factors for Small Intestine Bacterial Overgrowth (SIBO) in CD patients in a retrospective series of 110 patients ${ }^{(19)}$. Overall, the prevalence of SIBO was $30 \%$ in this population and more frequent in patients with the stricturing phenotype ( $48.5 \%$ vs $19.5 \%$ in those without stenosis). Active screening for SIBO, mostly in symptomatic patients with associated the stricturing phenotype, may improve the detection of this essential entity, leading to adequate treatment and symptomatic improvement in CD patients, even those in remission.

The recent development of basic science research in IBD in Brazil can be illustrated by the study from Lins Neto et al. ${ }^{(20)}$. Diagnosis of IBD can be challenging, and even with adequate invasive methods such as colonoscopy, the differential diagnosis between $\mathrm{CD}$ and UC can be difficult. The use of metabolomics to support IBD diagnosis is more recently discussed, and this study with fecal samples demonstrated the feasibility of metabolomics as biomarkers for differential diagnosis. The use of high resolution nuclear magnetic resonance hydrogen spectroscopy demonstrated that some metabolites, such as lactate, succinate, alanine, and tyrosine, may be more prevalent in $\mathrm{CD}$ fecal samples, whereas leucine, alanine, and tyrosine can be more prevalent in UC, in different combinations. Authors place metabolomic analysis as a promising differential diagnosis method between $\mathrm{CD}$ and $\mathrm{UC}$, as a non-invasive biomarker.

Lastly, Lima et al. bring us a detailed critical narrative review of the role of anti-TNF agents in the era of biologics with different mechanisms of action and new small molecules ${ }^{(21)}$. It is important to understand that it is not because new therapies are available that 
we may limit classical treatment options such as anti-TNF agents. Authors emphasize that the choice and positioning of biological agents may be difficult and should consider different variables such as physician experience, disease characteristics, and available scientific data. Anti-TNFs should be considered as first-line therapy in specific situations such as perianal fistulizing $C D$, patients with extraintestinal manifestations (e.g., ankylosing spondylitis), and hospitalized acute severe colitis patients not responding to intravenous corticosteroids (infliximab). Data in these specific scenarios are more solid with the use of TNF inhibitors than other biologics and demonstrate that these agents still constitute a leading option in IBD management, despite newly available drugs.

Recently, Arquivos de Gastroenterologia became the official scientific journal of GEDIIB (Grupo de Estudos de Doenças Inflamatórias Intestinais do Brasil), the Brazilian national study group of IBD. This occurs ten years after the publication of the national guidelines in this journal ${ }^{(22)}$. The aforementioned articles are recent examples of Brazilian research quality coming from GEDIIB, as all manuscripts have active members of the study group as main authors, co-authors or senior authors. The partnership between the study group and this journal is a promising step forward in IBD Brazilian research in different fields such as epidemiology, basic science, clinical and surgical management of both CD and UC. At the end of the line, applying the findings of different national studies in clinical practice may impact the final target for all of those who treat IBD: our patients. Improved care aiming clinical remission and restored quality of life results from good research and updated clinical care pathways. May our patients benefit from this growing interest in the IBD field in our country.

Paulo Gustavo KOTZE Adérson Omar Mourão Cintra DAMIÃO²

Kotze PG, Damião AOMC. Pesquisa em doenças inflamatórias intestinais no Brasil: um passo à frente rumo ao cuidado dos pacientes. Arq Gastroenterol. 2020;57(3):225-6.

\section{REFERENCES}

1. Sandborn WJ, Feagan BG, Rutgeerts P, Hanauer S, Colombel JF, Sands BE, et al Vedolizumab as induction and maintenance therapy for Crohn's disease. N Engl J Med. 2013;369:711-21.

2. Sandborn WJ, Su C, Sands BE, D'Haens GR, Vermeire S, Schreiber S, et al Tofacitinib as induction and maintenance therapy for ulcerative colitis. N Engl J Med. 2017:376:1723-36.

3. Sands BE, Sandborn WJ, Panaccione R, O'Brien CD, Zhang H, Johanns J, et al Ustekinumab as induction and maintenance therapy for ulcerative colitis. N Engl J Med. 2019;381:1201-14

4. Peyrin-Biroulet L, Sandborn W, Sands BE, Reinisch W, Bemelman W, Bryant R V., et al. Selecting Therapeutic Targets in Inflammatory Bowel Disease (STRIDE) Determining Therapeutic Goals for Treat-to-Target. Am J Gastroenterol. 2015;110:1324-38.

5. Khanna R, Bressler B, Levesque BG, Zou G, Stitt LW, Greenberg GR, et al. Early combined immunosuppression for the management of Crohn's disease (REACT): A cluster randomised controlled trial. Lancet. 2015;386(10006):1825-34.

6. Ponsioen CY, de Groof EJ, Eshuis EJ, Gardenbroek TJ, Bossuyt PMM, Hart A, et al. Laparoscopic ileocaecal resection versus infliximab for terminal ileitis in Crohn's disease: a randomised controlled, open-label, multicentre trial. Lancet Gastroenterol Hepatol. 2017;2:785-92.

7. Quaresma AB, Coy CSR, Damião AOMC, G Kaplan G, Kotze PG. Biological therapy penetration for inflammatory bowel disease in Latin America: Current status and future challenges. Arq Gastroenterol. 2019;56:318-22.

8. Quaresma AB, Kaplan GG, Kotze PG. The globalization of inflammatory bowel disease: The incidence and prevalence of inflammatory bowel disease in Brazil Current Opinion in Gastroenterology. 2019;35:259-64.

9. Kotze PG, Underwood FE, Damião AOMC, Ferraz JGP, Saad-Hossne R, Toro M, et al. Progression of Inflammatory Bowel Diseases Throughout Latin America and the Caribbean: A Systematic Review. Clin Gastroenterol Hepatol. 2020;18:304-12.

10. Kaplan GG, Ng SC. Understanding and Preventing the Global Increase of Inflammatory Bowel Disease. Gastroenterology. 2017;152:313-321.e2.

11. Ng SC, Shi HY, Hamidi N, Underwood FE, Tang W, Benchimol EI, et al. Worldwide incidence and prevalence of inflammatory bowel disease in the 21st century: a systematic review of population-based studies. Lancet. 2017;390:2769-78.

12. De Souza HSP. Etiopathogenesis of inflammatory bowel disease: Today and tomorrow. Curr Opin Gastroenterol. 2017;33:222-9.
13. Magro DO, Cazzo E, Kotze PG, Vasques ACJ, Martinez CAR, Chaim EA, et al Glucose Metabolism Parameters and Post-Prandial GLP-1 and GLP-2 Release Largely Vary in Several Distinct Situations: a Controlled Comparison Among Individuals with Crohn's Disease and Individuals with Obesity Before and After Bariatric Surgery. Obes Surg. 2018;28:378-88.

14. Kotze PG, Magro DO, Martinez CAR, Saab B, Saab MP, Pinheiro LV, et al. Adalimumab and postoperative complications of elective intestinal resections in Crohn's disease: a propensity score case-matched study. Colorectal Dis. 2018;20:211-8.

15. Kotze PG, Magro DO, Martinez CAR, Spinelli A, Yamamoto T, Warusavitarne J, et al. Long Time from Diagnosis to Surgery May Increase Postoperative Complication Rates in Elective CD Intestinal Resections: An Observational Study. Gastroenterol Res Pract. 2018;2018:4703281.

16. De Souza HSP, Fiocchi C, Iliopoulos D. The IBD interactome: An integrated view of aetiology, pathogenesis and therapy. Nat Rev Gastroenterol Hepatol. 2017;14:739-49.

17. Queiroz NSF, Saad-Hossne R, Fróes RSB, Penna FGC, Gabriel SB, Martins AL, Teixeira FV. Discontinuation rates following a switch from a reference to a biosimilar biologic in patients with inflammatory bowel disease: a systematic review and meta-analysis. Arq Gastroenterol. 2020;57:232-43.

18. Parra RS, Feitosa MR, Ferreira SC, Rocha JJR, Troncon LEA, Féres O. Anemia and iron deficiency in inflammatory bowel disease patients in a referral center in Brazil : prevalence and risk factors. Arq Gastroenterol. 2020;57:272-7.

19. Bertges ER, Chebli JM. Prevalence and factors associated with small intestina bacterial overgrowth in patients with Crohn's disease: a retrospective study at a referral center. Arq Gastroenterol. 2020;57:283-8.

20. Lins Neto MAF, Verdi GMX, Veras AO, Veras MO, Caetano LC, Ursulino JS Use of metabolomics to the diagnosis of inflammatory bowel disease. Arq Gastroenterol. 2020;57:311-5.

21. Lima CCG, Queiroz NSF, Sobrado CW, Silva GLR, Nahas SC. Critical analysis of anti-TNF use in the era of new biological agents in inflammatory bowel disease. Arq Gastroenterol. 2020;57:323-32.

22. Da Pontte ACA, Damião AOMC, Rosa AM, Da Silva AN, Fachin AV, Cortecazzi A, et al. Consensus guidelines for the management of inflammatory bowel disease. Arq Gastroenterol. 2010;47:313-25. 